Prepared in cooperation with the Washington State Department of Ecology

Suspended-Sediment Transport from the Green-Duwamish River to the Lower Duwamish Waterway, Seattle, Washington, 2013-17

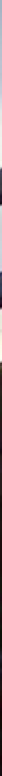

Open-File Report 2018-1029

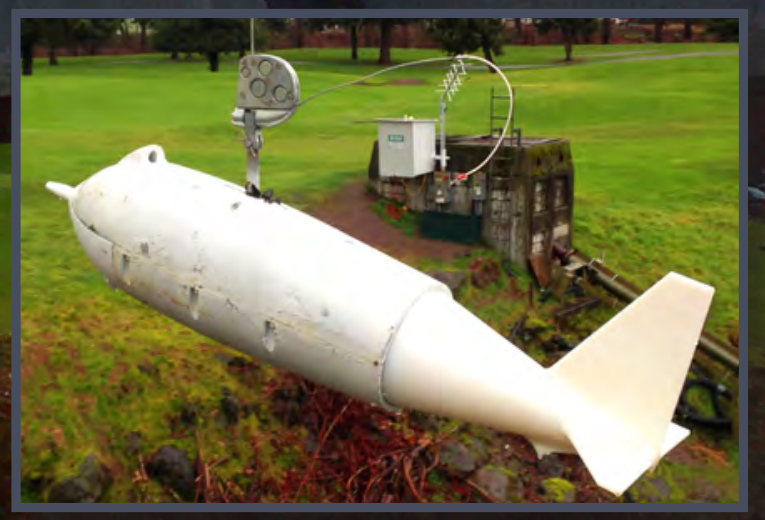

U.S. Department of the Interior

U.S. Geological Survey 
Cover: Photograph showing U.S. Geological Survey field crew collecting water samples at U.S. Geological Survey streamgage 12113390 (Duwamish River at Golf Course, at Tukwila, WA). Photograph by Kathleen Conn, January 11, 2017.

Inset: Photograph showing U.S. Geological Survey D-96 water sampler, with U.S. Geological Survey streamgage 12113390 (Duwamish River at Golf Course, at Tukwila, WA) in the background. Photograph by Kathleen Conn, January 2014 


\section{Suspended-Sediment Transport from the Green- Duwamish River to the Lower Duwamish Waterway, Seattle, Washington, 2013-17}

By Craig A. Senter, Kathleen E. Conn, Robert W. Black, Norman Peterson, Ann Vanderpool-Kimura, and James R. Foreman

Prepared in cooperation with the Washington State Department of Ecology

Open-File Report 2018-1029

U.S. Department of the Interior

U.S. Geological Survey 


\section{U.S. Department of the Interior \\ RYAN K. ZINKE, Secretary}

\section{U.S. Geological Survey \\ William H. Werkheiser, Deputy Director \\ exercising the authority of the Director}

U.S. Geological Survey, Reston, Virginia: 2018

For more information on the USGS-the Federal source for science about the Earth, its natural and living resources, natural hazards, and the environment-visit https://www.usgs.gov/ or call 1-888-ASK-USGS (1-888-275-8747).

For an overview of USGS information products, including maps, imagery, and publications, visit https:/store.usgs.gov.

Any use of trade, firm, or product names is for descriptive purposes only and does not imply endorsement by the U.S. Government.

Although this information product, for the most part, is in the public domain, it also may contain copyrighted materials as noted in the text. Permission to reproduce copyrighted items must be secured from the copyright owner.

Suggested citation:

Senter, C.A., Conn, K.E., Black, R.W., Peterson, N., Vanderpool-Kimura, A., and Foreman, J.R., 2018, Suspendedsediment transport from the Green-Duwamish River to the Lower Duwamish Waterway, Seattle, Washington, 2013-17: U.S. Geological Survey Open-File Report 2018-1029, 23 p., https://doi.org/10.3133/ofr20181029.

ISSN 2331-1258 (online) 


\section{Contents}

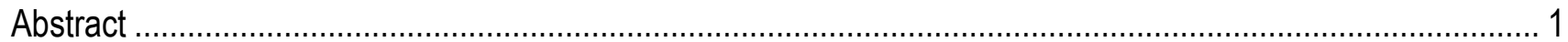

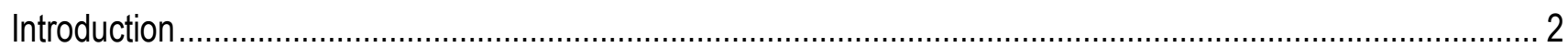

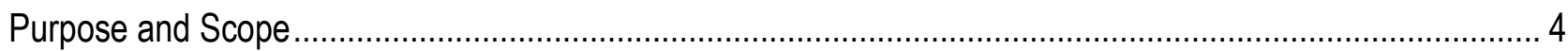

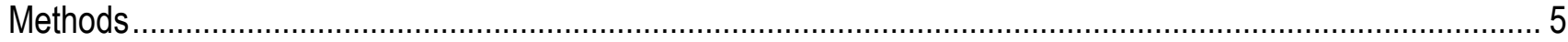

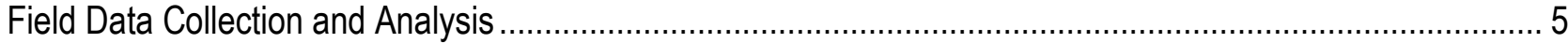

Discrete Water Samples for Suspended-Sediment Concentration and Particle-Size Distribution................ 5

Time-Series Data of Turbidity, Discharge, and Stage .................................................................... 5

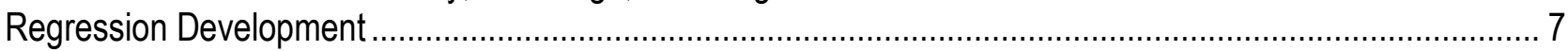

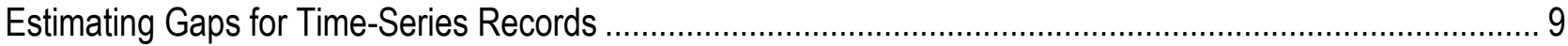

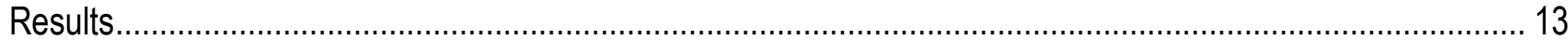

River Discharge, Turbidity, and Sediment during the Study Period ........................................................ 13

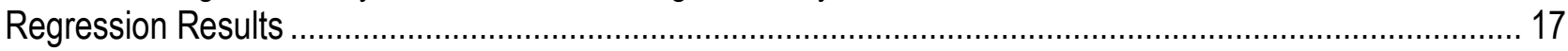

Suspended-Sediment Concentration-Turbidity Regression.......................................................... 17

Suspended-Sediment Concentration Fines (Particles Less Than 0.0625 Millimeter in Diameter)-Turbidity

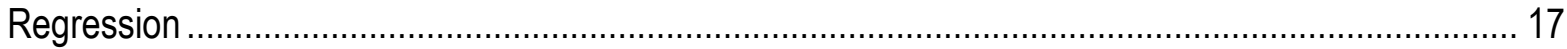

Suspended-Sediment Concentration-Discharge Regression ............................................................. 17

Suspended-Sediment Concentration (Particles Less Than 0.0625 Millimeter in Diameter)-Discharge

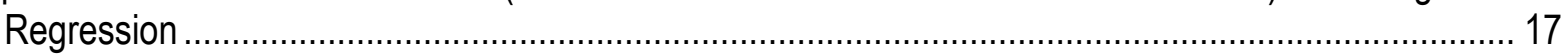

Time-Series Suspended-Sediment Concentration and Load Calculations ................................................. 19

Comparison to Previous Sediment Load Estimates ................................................................................ 19

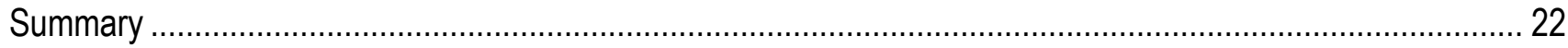

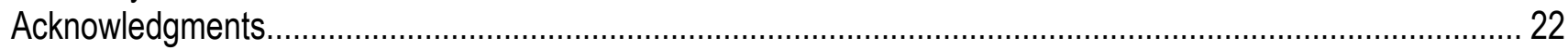

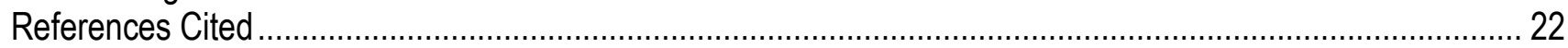

\section{Figures}

Figure 1. U.S. Geological Survey (USGS) streamgage 12113390 (Duwamish River at Golf Course at Tukwila, Washington) relative to the Lower Duwamish Waterway, Seattle, Washington .................................. 3 Figure 2. Selected sampling location, U.S. Geological Survey streamgage 12113390 (Duwamish River at Golf Course at Tukwila, Washington), located at river kilometer 16.7.

Figure 3. Photographs of $(A)$ U.S. Geological Survey streamgage 12113390 (Duwamish River at Golf Course at Tukwila, Washington), (B) US D-96 sampler for suspended-sediment water samples, $(C)$ turbidity sensor, and $(D)$ two acoustic Doppler velocity meters.

Figure 4. Regression between instantaneous measurements of turbidity with a SonTek ${ }^{\circledR}$ YSI 6920-V2-2 (YSI) and 15-minute values with a DTS-12 sensor (DTS12)—confidence bounds are upper and lower 90 percent probability—at U.S. Geological Survey streamgage 12113390 (Duwamish River at Golf Course at Tukwila, WA)

Figure 5. Workflow chart showing methods used to compute suspended-sediment loads, Lower Duwamish Waterway....

Figure 6. Logarithmic regression between discharge and stage at U.S. Geological Survey streamgage 12113390 (Duwamish River at Golf Course at Tukwila, WA)

Figure 7. Linear regression between discharge at U.S. Geological Survey (USGS) streamgage 12113390 (Duwamish River at Golf Course at Tukwila, WA) and discharge at USGS streamgage 12113000 (Green River near Auburn, WA). 
Figure 8. Continuous record of discharge constructed from the approved record (blue), estimated from stage (red), estimated from discharge at the next upstream gage (green), and estimated using linear interpolation (orange), U.S. Geological Survey streamgage 12113390 (Duwamish River at Golf Course at Tukwila, WA), November-December 2014

Figure 9. Discharge duration curve, U.S. Geological Survey streamgage 12113390 (Duwamish River at Golf Course at Tukwila, WA), November 2013-January 2017

Figure 10. Turbidity duration curve, U.S. Geological Survey streamgage 12113390 (Duwamish River at Golf Course at Tukwila, WA), November 2013-January 2017.

Figure 11. Suspended-sediment concentration (SSC) regression model plots with associated upper and lower 90 percent confidence bounds. (A) $\log 10$ SSC versus $\log 10$ Turbidity; (B) $\log 10$ SSC versus $\log 10$ Discharge; (C) log10 SSC fines versus log10 Turbidity; (D) log10 SSC fines versus log10 Discharge

Figure 12. Daily mean discharge for study period with overlapping historical mean daily discharge, U.S. Geological Survey streamgage 12113000 (Green River near Auburn, WA), Washington .

\section{Tables}

Table 1. Turbidity and discharge surrogate regression models computing suspended-sediment concentration (SSC) with the number of paired samples for their respective models.

Table 2. Suspended-sediment concentration, suspended-sediment concentration of fines, turbidity, and discharge samples collected at U.S. Geological Survey streamgage 12113390 (Duwamish River at Golf Course at Tukwila, WA)

\section{Conversion Factors}

International System of Units to U.S. customary units

\begin{tabular}{|c|c|c|}
\hline Multiply & By & To obtain \\
\hline \multicolumn{3}{|c|}{ Length } \\
\hline centimeter $(\mathrm{cm})$ & 0.3937 & inch (in.) \\
\hline millimeter (mm) & 0.03937 & inch (in.) \\
\hline meter $(\mathrm{m})$ & 3.281 & foot $(\mathrm{ft})$ \\
\hline kilometer $(\mathrm{km})$ & 0.6214 & mile (mi) \\
\hline kilometer $(\mathrm{km})$ & 0.5400 & mile, nautical (nmi) \\
\hline meter $(\mathrm{m})$ & 1.094 & yard $(y d)$ \\
\hline \multicolumn{3}{|c|}{ Area } \\
\hline square kilometer $\left(\mathrm{km}^{2}\right)$ & 0.3861 & square mile $\left(\mathrm{mi}^{2}\right)$ \\
\hline
\end{tabular}

U.S. customary units to International System of Units

\begin{tabular}{|c|c|c|}
\hline Multiply & By & To obtain \\
\hline \multicolumn{3}{|c|}{ Length } \\
\hline inch (in.) & 2.54 & centimeter $(\mathrm{cm})$ \\
\hline foot $(\mathrm{ft})$ & 0.3048 & meter $(\mathrm{m})$ \\
\hline \multicolumn{3}{|c|}{ Flow } \\
\hline cubic foot per second $\left(\mathrm{ft}^{3} / \mathrm{s}\right)$ & 0.0283 & cubic meter per second $\left(\mathrm{m}^{3} / \mathrm{s}\right)$ \\
\hline \multicolumn{3}{|c|}{ Mass } \\
\hline ton, short $(2,000 \mathrm{lb})$ & 0.9072 & metric ton $(\mathrm{t})$ \\
\hline
\end{tabular}




\section{Datum}

Horizontal coordinate information is referenced to the North American Datum of 1983 (NAD 83).

\section{Abbreviations}

$\begin{array}{ll}\text { ADCP } & \text { acoustic Doppler current profiler } \\ \text { ADVM } & \text { acoustic Doppler velocity meter } \\ \text { BCF } & \text { non-parametric smearing bias correction factor } \\ \text { CVO } & \text { Cascades Volcano Observatory } \\ \text { EPA } & \text { U.S. Environmental Protection Agency } \\ \text { EDI } & \text { equal-discharge increment } \\ \text { FNU } & \text { Formazin Nephelometric Unit } \\ \text { LDW } & \text { Lower Duwamish Waterway } \\ \text { NWIS } & \text { National Water Information System } \\ \text { R2 } & \text { coefficient of determination } \\ \text { RKM } & \text { river kilometer } \\ \text { RMSE } & \text { root-mean-square error } \\ \text { SAID } & \text { Surrogate Analysis and Index Developer } \\ \text { SSC } & \text { suspended-sediment concentration per volume of water } \\ \text { SSCFINES } & \text { suspended-sediment concentration of particles less than } 0.0625 \text { millimeter in diameter per volume of water } \\ \text { SSL } & \text { suspended-sediment load } \\ \text { SSLFINES } & \text { suspended-sediment load of particles less than } 0.0625 \text { millimeter in diameter } \\ \text { STM } & \text { Sediment Transport Model } \\ \text { USGS } & \text { U.S. Geological Survey }\end{array}$


This page left intentionally blank 


\section{Suspended-Sediment Transport from the Green- Duwamish River to the Lower Duwamish Waterway, Seattle, Washington, 2013-17}

By Craig A. Senter, Kathleen E. Conn, Robert W. Black, Norman Peterson, Ann Vanderpool-Kimura, and James R. Foreman

\section{Abstract}

The Green-Duwamish River transports watershed-derived sediment to the Lower Duwamish Waterway Superfund site near Seattle, Washington. Understanding the amount of sediment transported by the river is essential to the bed sediment cleanup process. Turbidity, discharge, suspended-sediment concentration (SSC), and particle-size data were collected by the U.S. Geological Survey (USGS) from February 2013 to January 2017 at the Duwamish River, Washington, within the tidal influence at river kilometer 16.7 (USGS streamgage 12113390; Duwamish River at Golf Course at Tukwila, WA). This report quantifies the timing and magnitude of suspended-sediment transported in the Duwamish River. Regression models were developed between SSC and turbidity and SSC and discharge to estimate 15minute SSC. Suspended-sediment loads were calculated from the computed SSC and time-series discharge data for every 15-minute interval during the study period. The 2014-16 average annual suspended-sediment load computed was 117,246 tons (106,364 metric tons), of which 73.5 percent or (86,191 tons; 78,191 metric tons) was fine particle (less than 0.0625 millimeter in diameter) suspended sediment. The seasonality of this site is apparent when you divide the year into "wet" (October 16April 15) and "dry" (April 16-October 15) seasons. Most (97 percent) of the annual suspended sediment was transported during the wet season, when brief periods of intense precipitation from storms, large releases from the Howard Hanson Dam, or a combination of both were much more frequent. 


\section{Introduction}

The Lower Duwamish Waterway (LDW) is the final 8-km-long reach of the Green-Duwamish River. The LDW terminates into Puget Sound's Elliott Bay in Seattle, Washington (fig. 1) and is a site affected by contaminated sediments due to past and present anthropogenic activities. In 2001-02, the U.S. Environmental Protection Agency (EPA) and the Washington State Department of Ecology (Ecology) required remedial investigations and feasibility studies on the $1.8 \mathrm{~km}^{2} \mathrm{LDW}$ under the Federal Superfund law (U.S. Environmental Protection Agency, 2018) and the Washington Model Toxics Control Act (Washington State Department of Ecology, 2013) because of concerns about human health and ecological risks from exposure to contaminated sediments. For that reason, it is critical to have a better understanding of how much suspended sediment is being transported and subsequently deposited in the LDW.

Three major sources of sediment to the LDW are (1) re-suspended bed sediment in the LDW, (2) lateral sources from land adjacent to the LDW, and (3) upstream sources that are transported by the Green River to the Duwamish River-LDW (the river changes names from Green River to Duwamish River at the Black River confluence at river kilometer [RKM] 18; fig. 1). The river originates in the Cascade Mountains and travels approximately $150 \mathrm{~km}$ through an increasingly developed watershed to Elliott Bay, Puget Sound, Washington. The Howard Hanson Dam located at RKM 103 regulates discharge primarily for flood control.

The Sediment Transport Model (STM) developed for the LDW by AECOM Technology Corporation estimates that, on average, more than 204,000 tons (185,000 metric tons) of sediment enters the LDW each year. Greater than 99 percent of the sediment originates at upstream sources, whereas approximately 0.5 percent originates from lateral sources, and 0.2 percent originates from bed sediment in the LDW (Lower Duwamish Waterway Group, 2008). Additionally, the STM estimates that about 90 percent of the total bed area in the LDW will receive $10 \mathrm{~cm}$ of new sediment within 10 years or less. The contaminants of concern in the LDW (polychlorinated biphenyls, arsenic, dioxins/furans, and polycyclic aromatic hydrocarbons) tend to be sorbed to sediment rather than dissolved in water. Therefore, the sediment transport and loading dynamics from the Green River to the LDW will determine, in large part, the sediment recovery potential of remediated areas in the LDW.

Limited field data are available regarding sediment transport and loading dynamics from the Green River to the LDW. The STM estimated suspended- and bed-sediment loading into the LDW from upstream sources using grain size information and a flow-rating curve for the Green River based on discharge data from 1960-80 and 1996-98 (Santos and Stoner, 1972; Embrey and Frans, 2003). The discharge data were from a U.S. Geological Survey (USGS) streamgage 12113000 (Green River near Auburn; hereinafter "USGS 12113000"), located more than 40 RKM upstream of the LDW. Flows at that streamgage were approximately 10 percent less than actual flows into the LDW because of additional inputs between the streamgage and the LDW (Lower Duwamish Waterway Group, 2008). This resulted in estimated sediment loads that may have underestimated actual values by 20-25 percent (Lower Duwamish Waterway Group, 2008). 


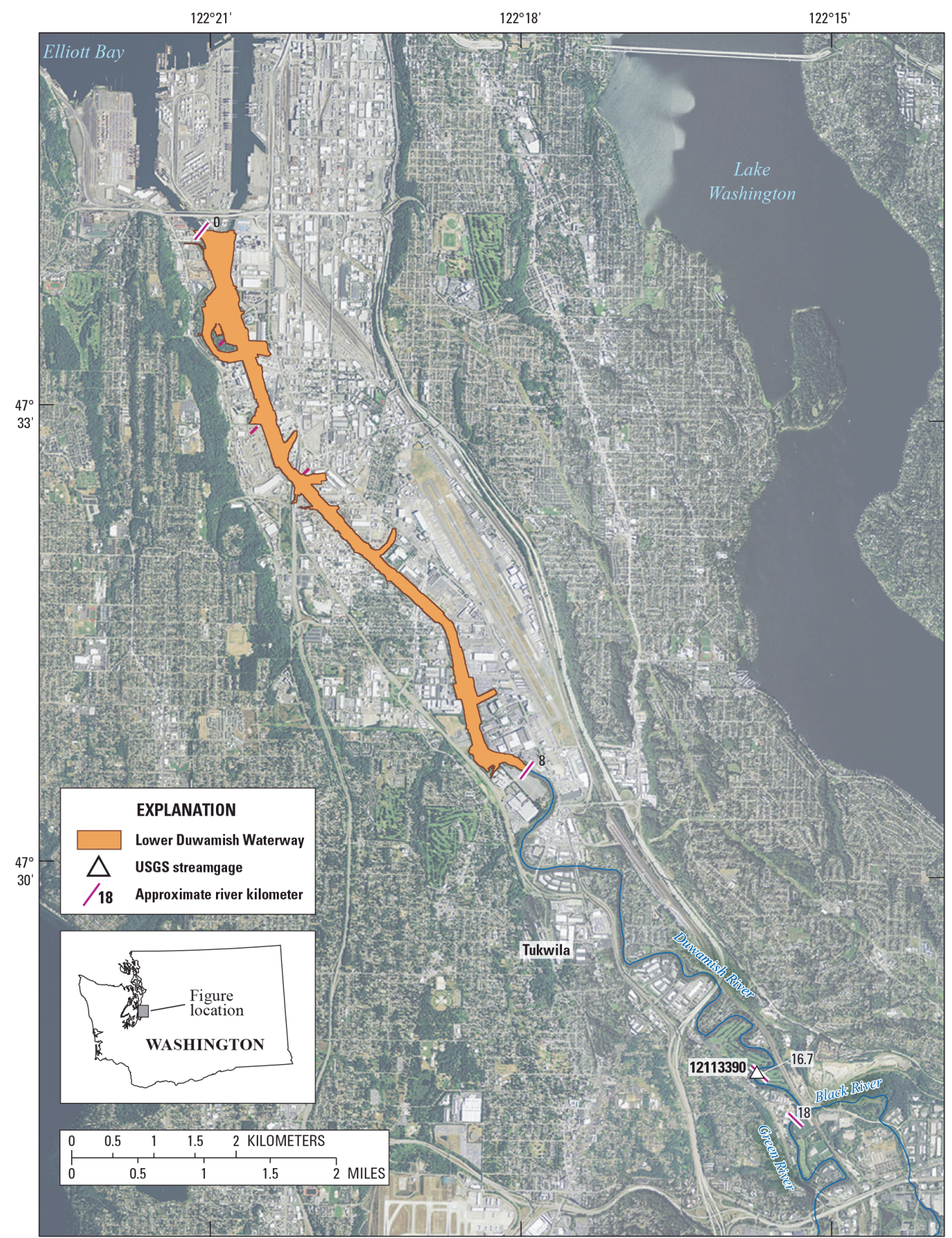

Base map from National Agricultural Imagery Program (NAIP), 2013, 1- meter imagery. Map projection:U.S. Department of Agriculture, Farm Service Agency, Washington State Plane South, horizontal datum in North American Datum of 1983 NAD83

Figure 1. U.S. Geological Survey (USGS) streamgage 12113390 (Duwamish River at Golf Course at Tukwila, Washington) relative to the Lower Duwamish Waterway, Seattle, Washington. Modified from Conn and Black (2014). 
The sampling location for this study was USGS 12113390 (figs. 1 and 2). This sampling location has a private bridge that facilitates access to the river at about RKM 16.7, which is upstream of the estuarine environment but still in the tidally influenced section of the basin. Sampling at this streamgage minimized the potential for collection of re-suspended sediment from the LDW and transported upstream during high tides.

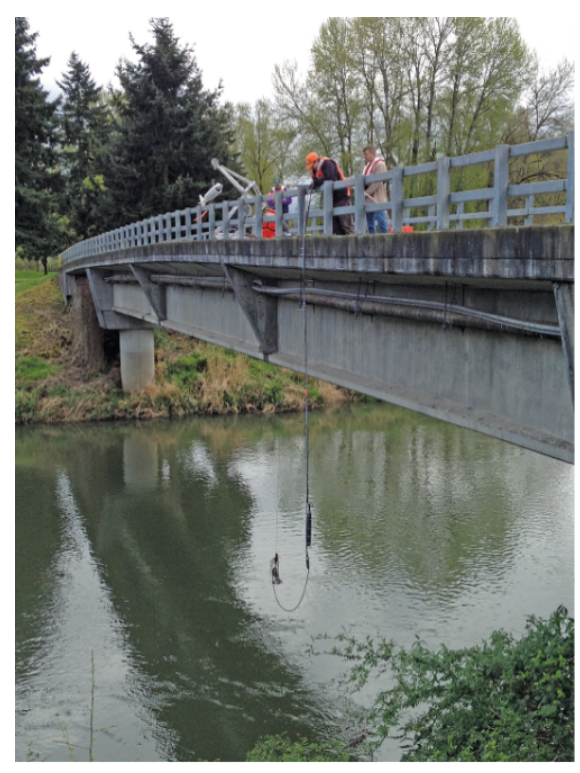

Figure 2. Selected sampling location, U.S. Geological Survey streamgage 12113390 (Duwamish River at Golf Course at Tukwila, Washington), located at river kilometer 16.7.

\section{Purpose and Scope}

This report presents data, collected by the U.S. Geological Survey in cooperation with the Washington State Department of Ecology, from discrete sampling of suspended sediment at USGS streamgage 12113390 on the Duwamish River upstream of the LDW from November 2013 to January 2017. Regression models were developed between suspended-sediment concentration (SSC) and turbidity and between SSC and discharge to provide a continuous time-series of SSC and suspendedsediment loads (SSL) associated with upstream sources in the Green River to the LDW. In order to provide a complete continuous time series of SSC, it was necessary to estimate 15-minute discharge values during periods of missing record. 


\section{Methods}

\section{Field Data Collection and Analysis}

Discrete suspended-sediment samples and time-series data were collected for the study period. The following sections describe the techniques and methods that were used to collect the data.

\section{Discrete Water Samples for Suspended-Sediment Concentration and Particle-Size Distribution}

From February 2013 to January 2017, 35 discrete samples were collected at USGS streamgage 12113390 (fig. $3 A$ ) for the analysis of SSC (the mass of suspended sediment per volume of water, reported in milligrams per liter) and SSCFINES (the mass of suspended sediment with a particle diameter less than $0.0625 \mathrm{~mm}$ per volume of water, reported in milligrams per liter). Water samples were collected using the equal-discharge-increment (EDI) method (Edwards and Glysson, 1999) with a US D-96 sampler (Davis, 2001). The sampler was lowered from the water surface to the bed and back to the water surface at a consistent transit rate to collect an isokinetic, depth-integrated sample (fig. $3 B$ ). The process was repeated at four additional stations in the cross-section of equal discharge increments, and the five flow-integrated samples were composited into a single sample. Two sets of five samples ("A" and "B" set) were collected during each discrete sampling period, resulting in two composite samples per period. All samples were analyzed for SSC and particle-size distribution (including the percent of fine sediment) at the USGS Cascades Volcano Observatory Sediment Laboratory (CVO) in Vancouver, Washington, per USGS methods (Guy, 1969). The average of the "A" and "B" set results was reported. Instantaneous turbidity was measured mid-depth in the river thalweg during discrete SSC sampling using a hand-held multi-parameter sonde (SonTek ${ }^{\circledR}$ YSI 6920V2-2). The sonde was calibrated with a Formazin-based standard before each sampling event, following methods by Wagner and others (2006). All discrete data are stored in USGS's National Water Information System (NWIS) for public access and long-term storage (U.S. Geological Survey, 2017).

\section{Time-Series Data of Turbidity, Discharge, and Stage}

Continuous turbidity was recorded in Formazin Nephelometric Units (FNU) at USGS 12113390 from November 2013 through January 2017, with the exception of intermittent periods of instrument failure. Turbidity was measured using a Forest Technology Systems, Ltd., DTS-12 nephelometric turbidity sensor (Forest Technology Systems, Ltd.) enclosed in a bank-mounted, protective 2 in. $\times 20 \mathrm{ft}$ metal pipe that extended into the river channel from the left bank (fig. $3 C$ ). This mounting arrangement allowed turbidity measurements in an actively flowing part of the river channel and decreased the likelihood of debris accumulation around the sensor face or on the mounting hardware. The sensor was operated and maintained according to USGS protocols for continuous waterquality instruments (Wagner and others, 2006). The river cross-section at USGS 12113390 is wellmixed, with less than 2 FNU difference (often less than 0.5 FNU difference) between readings from the deployed sensor and readings from a hand-held sensor at multiple depths and locations along the cross-section. This was confirmed with four separate cross-sectional measurements during periods of low turbidity ( $<10 \mathrm{FNU}$ ). The time-series turbidity record was processed, reviewed, and approved for the entire period of record per USGS protocols for continuous water-quality data (Wagner and others, 2006). Turbidity is reported as 15-minute values from November 2013 to January 2017 (https://waterdata.usgs.gov/nwis/inventory/?site_no=12113390). 

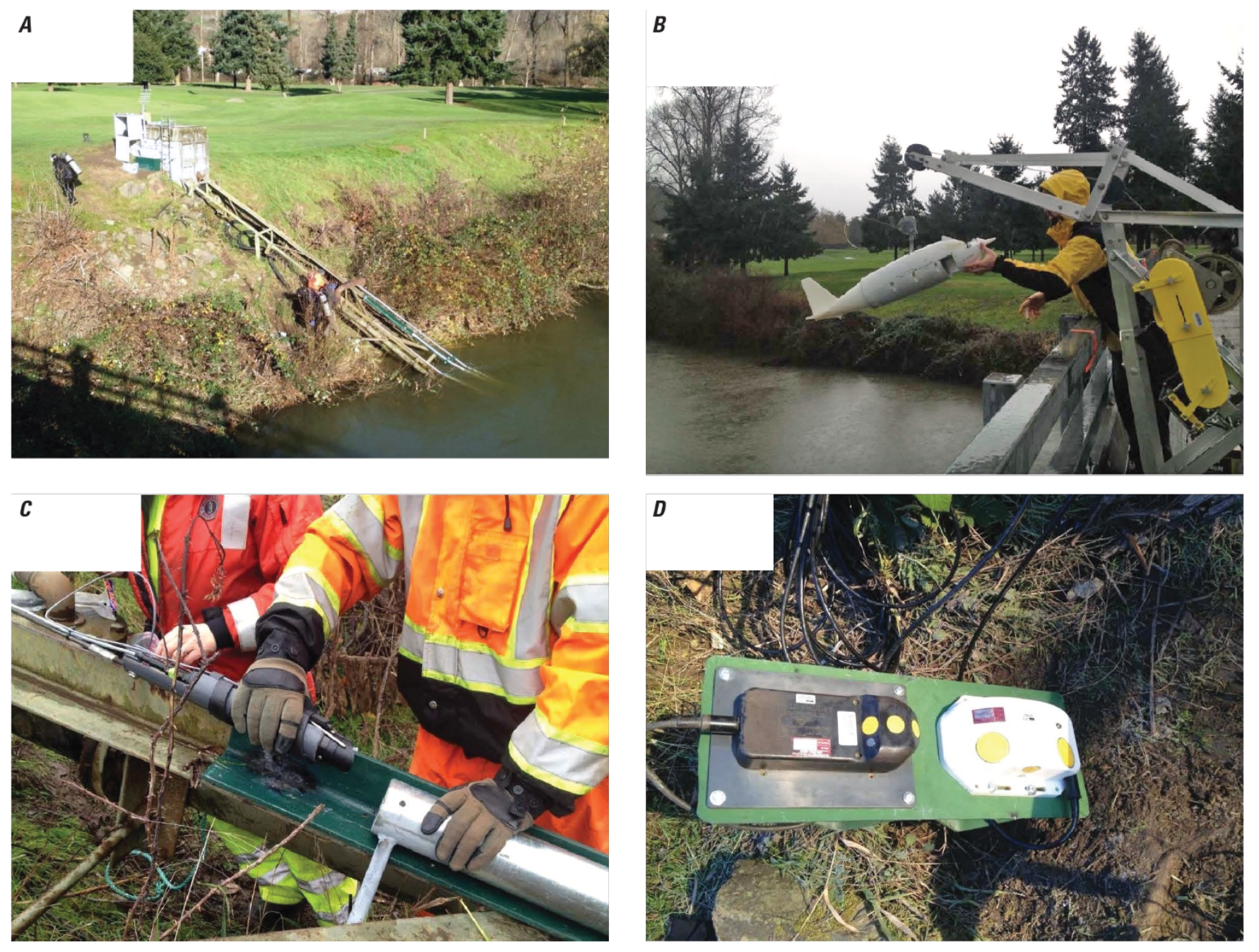

Figure 3. Photographs of (A) U.S. Geological Survey streamgage 12113390 (Duwamish River at Golf Course at Tukwila, Washington), (B) US D-96 sampler for suspended-sediment water samples, $(C)$ turbidity sensor, and (D) two acoustic Doppler velocity meters. Modified from Conn and Black (2015).

\section{Continuous discharge was recorded in $\mathrm{ft}^{3} / \mathrm{s}$ at USGS streamgage 12113390}

(https://waterdata.usgs.gov/nwis/inventory/?site_no=12113390) from November 2013 through January 2017, with the exception of intermittent periods of instrument failure. Discharge data were computed using the index-velocity method (Levesque and Oberg, 2012), which is used for tidally influenced stations with both upstream and downstream direction of flow. Data from the co-located acoustic Doppler velocity meter (ADVM; fig. $3 D$ ) was indexed to derive a mean velocity for the cross section. The indexed velocity was then used in conjunction with the stage-derived cross-sectional area to compute discharge at 15-minute intervals in the upstream and downstream direction past the tidally influenced station. The time-series stage and discharge records were processed, reviewed, and approved for the entire period of record (November 2013 through January 2017) per USGS protocols (Levesque and Oberg, 2012). Prior to November 2013, discrete measurements of river streamflow were collected using an acoustic Doppler current profiler (ADCP) following standard USGS protocols described by Turnipseed and Sauer (2010). All continuous data are stored in NWIS for public access and long-term storage (U.S. Geological Survey, 2017). 


\section{Regression Development}

Four single logarithmic (base 10) regression models were developed (table 1) with the Surrogate Analysis and Index Developer (SAID) software (Domanski and others, 2015) using turbidity or discharge as the explanatory (x) variable and SSC or SSC $\mathrm{FINES}_{\text {as }}$ the response (y) variable, per USGS methods (Rasmussen and others, 2009).

Both turbidity- and discharge-dependent regression models were developed from discrete SSC samples and either concurrently measured turbidity or discharge, calculated as the median of instantaneous values recorded during the sampling window (typically 30-60 minutes). When 15minute turbidity data was unavailable, values were estimated from a linear regression with instantaneous turbidity measured with a hand-held sonde (SonTek ${ }^{\circledR}$ YSI 6920-V2-2):

$$
\text { Turbidity }(D T S 12)=1.28 \times \text { Turbidity }(Y S I)+1.91 \text {, }
$$

where

Turbidity(DTS12) is the 15-minute turbidity measured by the deployed DTS-12 sensor, and

Turbidity(YSI) is instantaneous turbidity measured from the bridge with the handheld SonTek ${ }^{\circledR}$ YSI 6920-V2-2.

There was a strong linear correlation with an $\mathrm{R}^{2}$ of 0.998 (fig. 4).

When 15-minute discharge data was unavailable, discrete measurements of discharge with the ADCP were used instead. Details and statistical output are in the model archive summary for each regression (Senter and others, 2018).

Table 1. Turbidity and discharge surrogate regression models computing suspended-sediment concentration (SSC) with the number of paired samples for their respective models.

[RMSE: Root-mean-square error. R2: Coefficient of determination. Adjusted R2: Adjusted coefficient of determination. BCF: Non-parametric smearing bias correction factor. Abbreviations: SSC, suspended-sediment concentration; $\mathrm{SSC}_{\mathrm{FINES}}$, suspended-sediment concentration of particles less than 0.0625 millimeter in diameter]

\begin{tabular}{|c|c|c|c|c|c|c|c|}
\hline Regression & $\begin{array}{c}\text { Number of } \\
\text { paired } \\
\text { samples }\end{array}$ & $\begin{array}{c}\text { RMSE } \\
\text { (standard } \\
\text { error) }\end{array}$ & $\begin{array}{c}\text { RMSE } \\
\text { (percent) }\end{array}$ & $\mathbf{R}^{2}$ & $\begin{array}{c}\text { Adjusted } \\
\mathbf{R}^{2}\end{array}$ & $\begin{array}{c}\text { BCF } \\
\text { (bias } \\
\text { correction } \\
\text { factor) }\end{array}$ & $\begin{array}{c}\text { Probability plot } \\
\text { correlation } \\
\text { coefficient }\end{array}$ \\
\hline $\begin{array}{c}\text { Log10 Turbidity } \\
\text { - Log10 SSC }\end{array}$ & 29 & 0.136 & 32.2 & 0.952 & 0.951 & 1.05 & 0.991 \\
\hline $\begin{array}{c}\text { Log10 Turbidity } \\
- \text { Log10 } \\
\text { SSC FINES }\end{array}$ & 28 & 0.155 & 36.7 & 0.936 & 0.933 & 1.06 & 0.992 \\
\hline $\begin{array}{c}\text { Log10 Discharge } \\
- \text { Log10 SSC }\end{array}$ & 32 & 0.397 & 114.2 & 0.584 & 0.570 & 1.50 & 0.984 \\
\hline $\begin{array}{c}\text { Log10 Discharge } \\
- \text { Log10 }\end{array}$ & 31 & 0.407 & 118.7 & 0.539 & 0.523 & 1.50 & 0.988 \\
SSC & & & & & \\
\hline
\end{tabular}




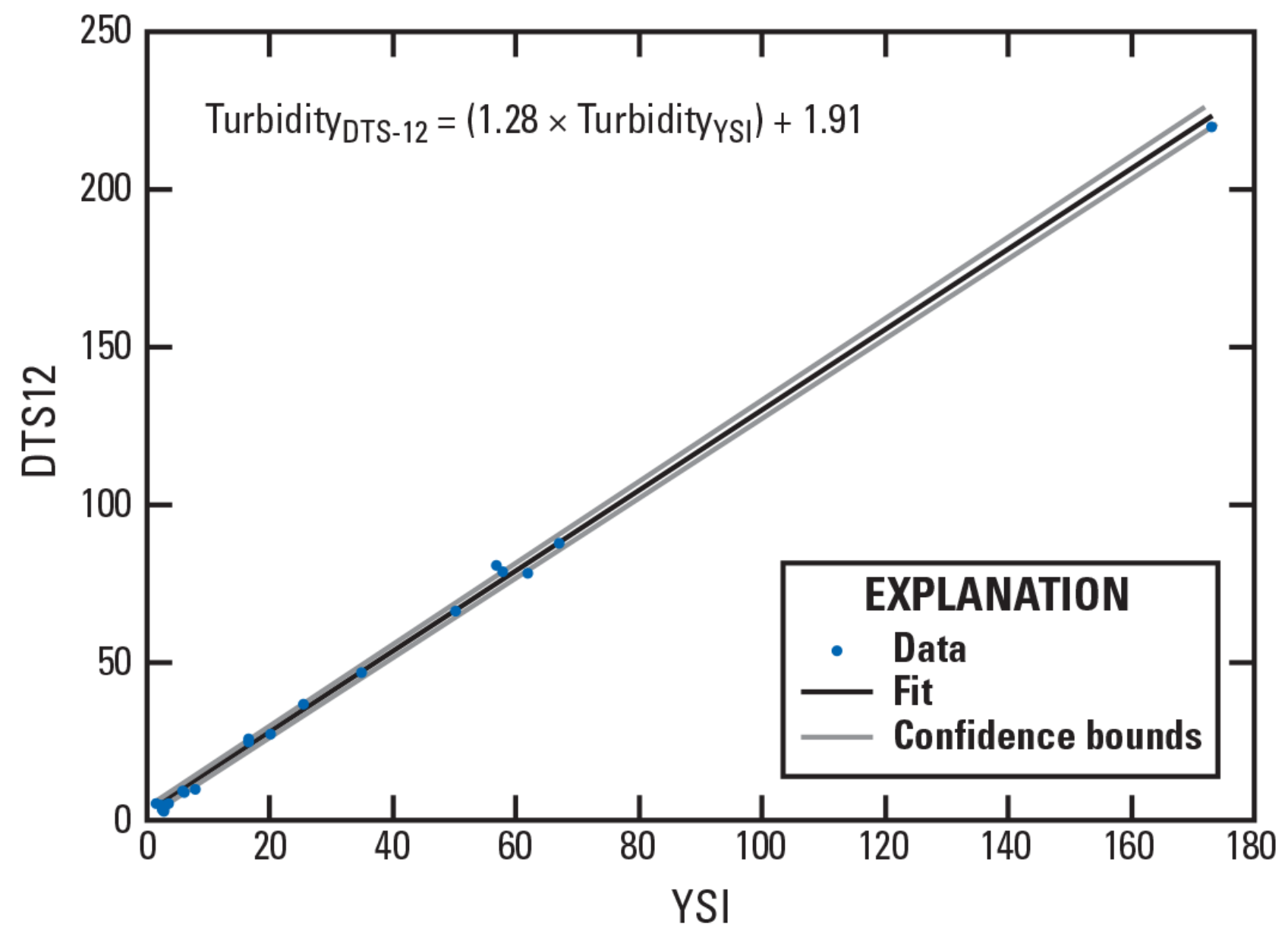

Figure 4. Regression between instantaneous measurements of turbidity with a SonTek ${ }^{\circledR}$ YSI 6920-V2-2 (YSI) and 15-minute values with a DTS-12 sensor (DTS12) — confidence bounds are upper and lower 90 percent probability—at U.S. Geological Survey streamgage 12113390 (Duwamish River at Golf Course at Tukwila, WA). 


\section{Estimating Gaps for Time-Series Records}

A continuous time-series record of turbidity and (or) discharge is needed to calculate continuous SSC and SSL. There was one long period of rejected turbidity data from September 28 to December 5, 2014, because of a slow optical failure of the turbidity sensor. The discharge record was used to calculate SSC during this period. Discharge also was missing during part of this period, from November 26 to December 5, 2014, because the ADVM was knocked askew by large debris during a high-flow event.

The preferred method to calculate a continuous record of SSC is to use a turbidity-SSC regression. When turbidity time-series data is missing, continuous SSC can be calculated based on a discharge-SSC regression instead. Missing data, or gaps, in the turbidity and discharge time-series records did occur periodically, and they were estimated following the procedural flowchart shown in figure 5 and described here. Some missing data occurred in short ( $\leq 6$ hour) gaps because of erratic turbidity sensor readings (spikes) or sensor maintenance. For these gaps, a linear interpolation between the values before and after the gap was used to fill in the missing turbidity and discharge data. Stable conditions were indicated by similar turbidity and discharge values before and after the gap and indicated by similar values of other time-series data during the gap. All gaps of turbidity and discharge that were linear interpolated had either less than a 10 percent change between estimates or were during a period when turbidity was less than $10 \mathrm{FNU}$ or discharge was less than $300 \mathrm{ft}^{3} / \mathrm{s}$. 


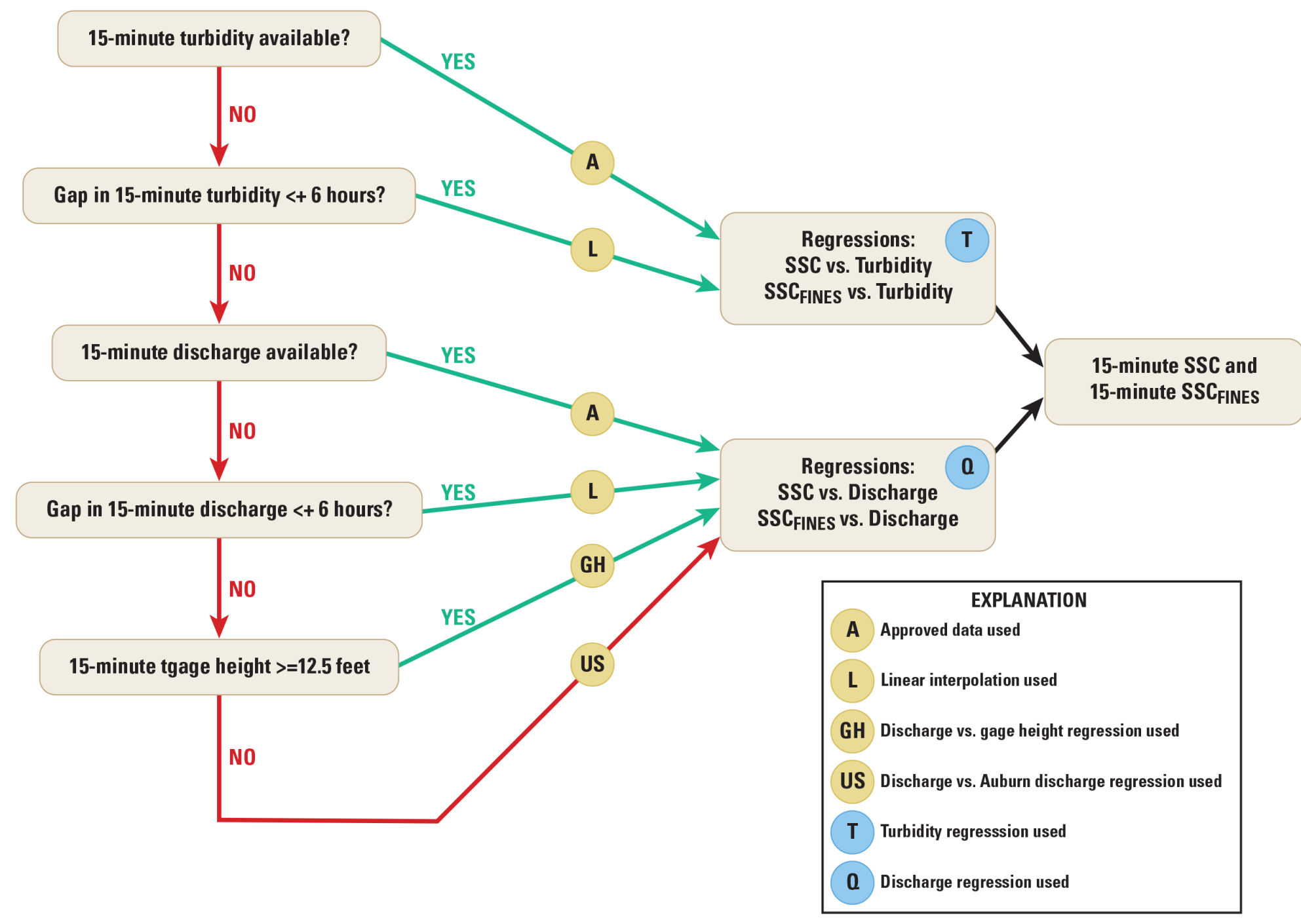

Figure 5. Workflow chart showing methods used to compute suspended-sediment loads, Lower Duwamish Waterway. SSC, suspended-sediment concentration; $S_{S C}$ FINES, suspended-sediment concentration of particles less than 0.0625 millimeter in diameter; vs., versus. 
A two-step process was used to fill the discharge gap between November 26 and December 5 , 2014:

1. For stages $12.5 \mathrm{ft}$ or more, discharge was estimated from a discharge-stage log 10 regression:

$$
\log 10(\text { Discharge }[\text { Stage } \geq 12.5 \mathrm{ft}])=2.00 \times \log 10(\text { Stage })+1.46
$$

The 12.5-ft stage threshold was selected because above $12.5 \mathrm{ft}$ the tidal influence at this site is minimal. The regression was based on 2,994 observations of paired 15-minute discharge and stage values during the approved period of record (November 2013-November 2015). The approved data used for this regression are available in NWIS (U.S. Geological Survey, 2017). The resulting regression had an $\mathrm{R}^{2}$ of 0.873 (fig. 6).

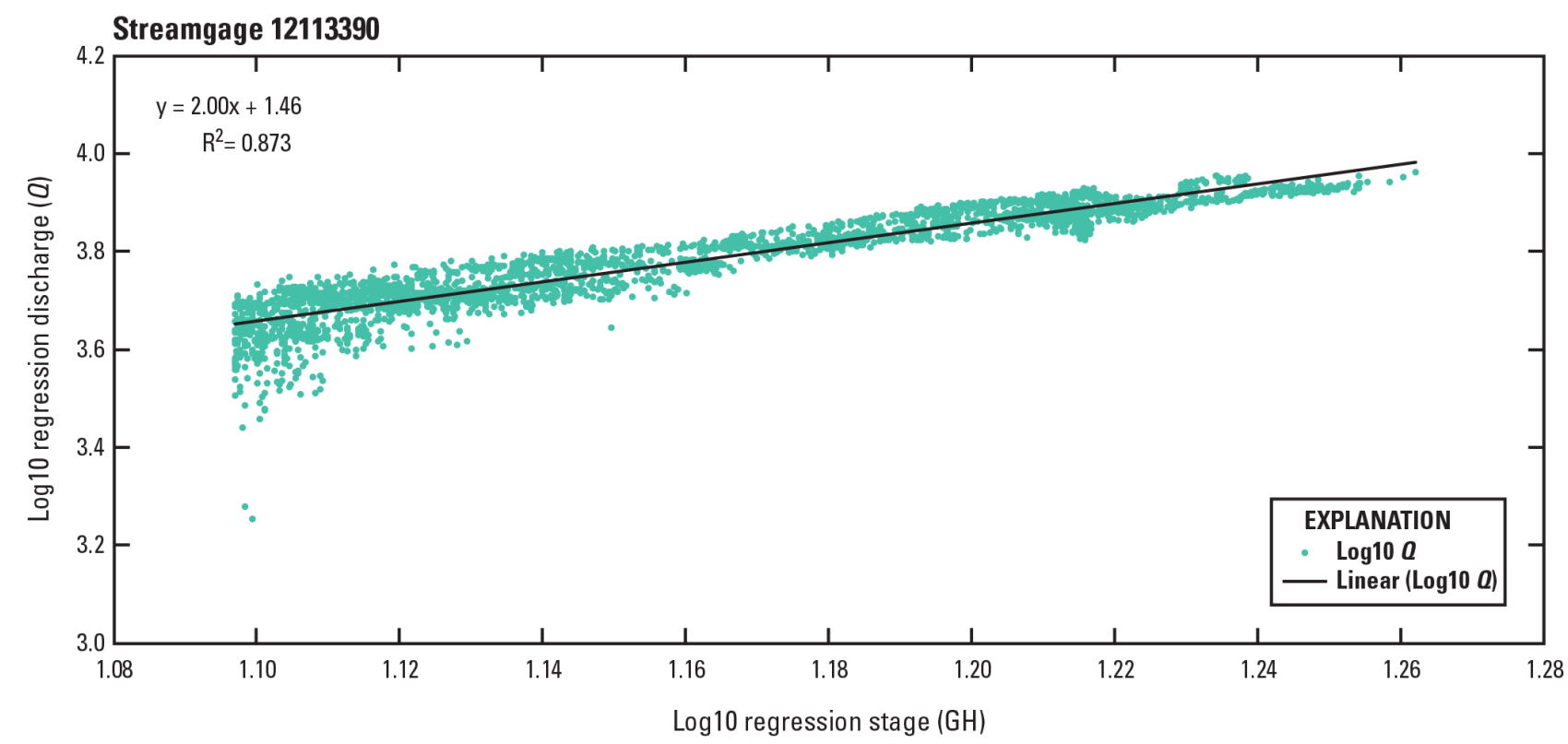

Figure 6. Logarithmic regression between discharge and stage at U.S. Geological Survey streamgage 12113390 (Duwamish River at Golf Course at Tukwila, WA). 
2. When stage declined below $12.5 \mathrm{ft}$, discharge was estimated from a linear regression with discharge 8 hours earlier (to account for travel time) from the next upstream discharge streamgage (USGS 12113000):

Discharge $(12113390)=$ Discharge $([12113000] 8$ hours earlier $)+138.55$,

where

Discharge(12113390) is discharge at U.S. Geological Survey streamgage 12113390 (Duwamish River at Golf Course at Tukwila, WA), and Discharge([12113000] 8 hours earlier) is discharge at U.S. Geological Survey streamgage 12113000 (Green River near Auburn, WA) 8 hours prior to Discharge(12113390).

The travel time was estimated based on comparisons of several peak to peak travel times between USGS streamgage 12113000 and USGS streamgage 12113390. The regression was based on 34,772 observations of paired 15-minute discharge values over all stages from both gages during the approved period of record (November 2013-November 2014). The approved data used for this regression are available in NWIS (U.S. Geological Survey, 2017). The resulting regression had an $\mathrm{R}^{2}$ of 0.944 (fig. 7).

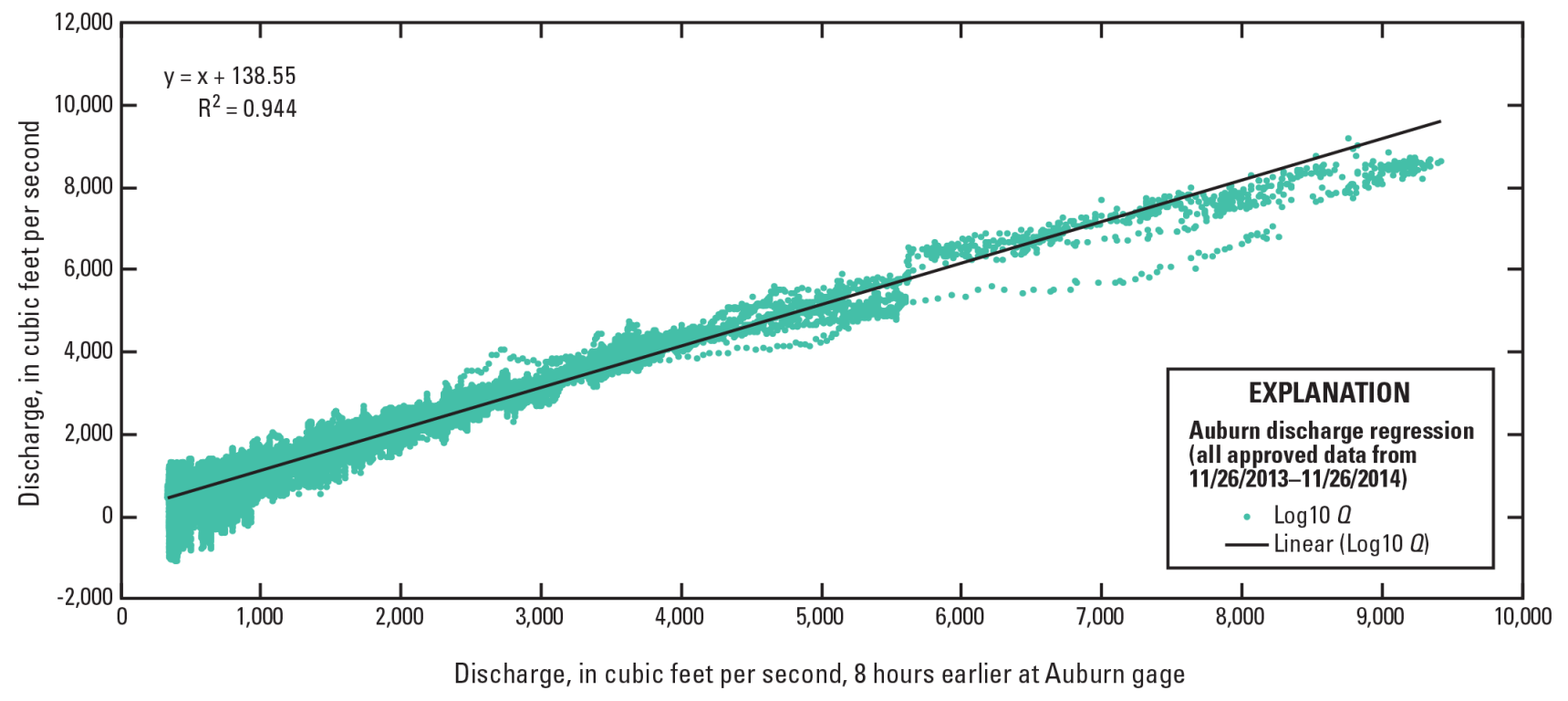

Figure 7. Linear regression between discharge at U.S. Geological Survey (USGS) streamgage 12113390 (Duwamish River at Golf Course at Tukwila, WA) and discharge at USGS streamgage 12113000 (Green River near Auburn, WA). 
A continuous record was produced using these two regressions to estimate discharge for this period of missing data (fig. 8).

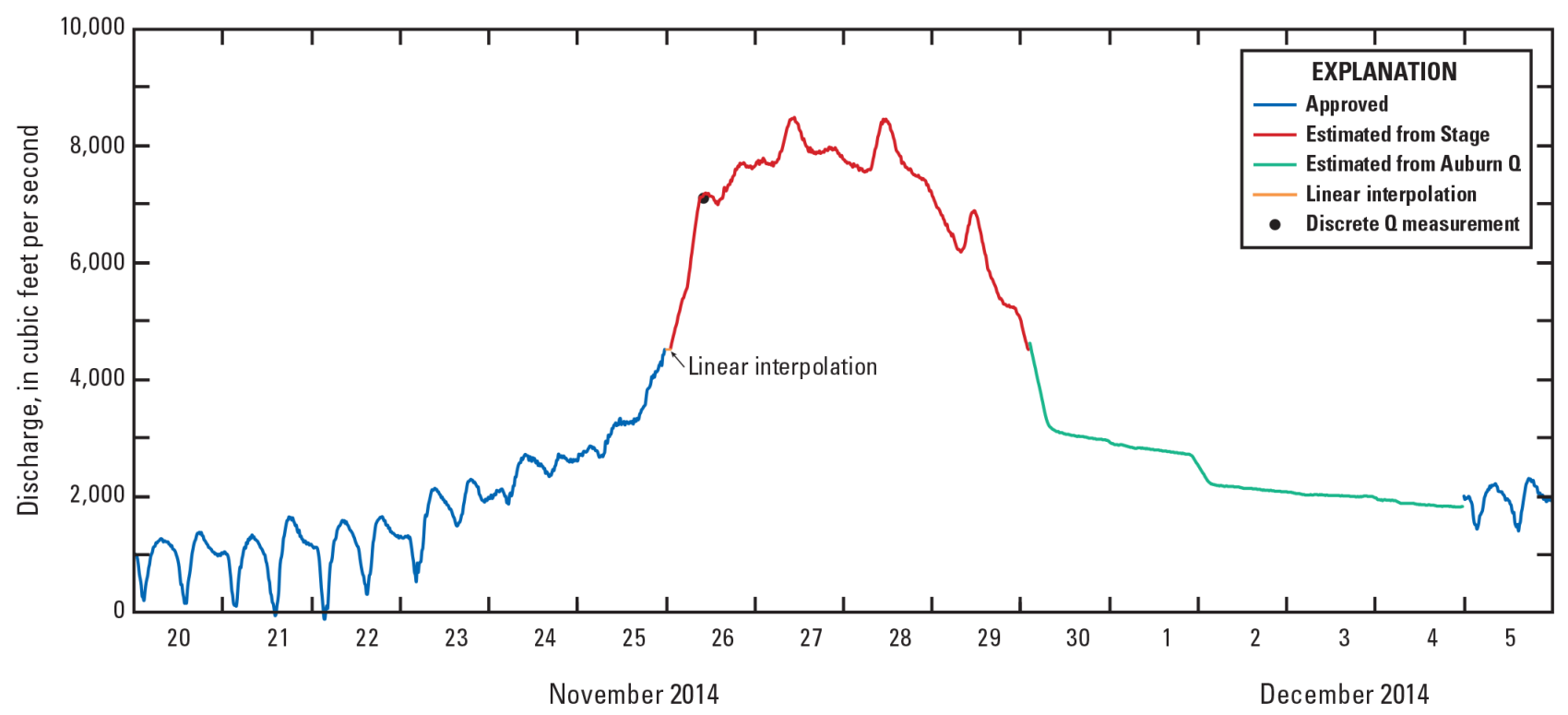

Figure 8. Continuous record of discharge constructed from the approved record (blue), estimated from stage (red), estimated from discharge at the next upstream gage (green), and estimated using linear interpolation (orange), U.S. Geological Survey streamgage 12113390 (Duwamish River at Golf Course at Tukwila, WA), November-December 2014.

\section{Results}

\section{River Discharge, Turbidity, and Sediment during the Study Period}

Discharge at river kilometer 16.7 in the Duwamish River during the study period ranged from $1,390 \mathrm{ft}^{3} / \mathrm{s}$ (the negative sign indicates flow in the upstream direction) to $+11,100 \mathrm{ft}^{3} / \mathrm{s}$. The river flow is regulated by the Howard Hanson Dam located at RKM 103, and discharge is maintained between 300 and $12,000 \mathrm{ft}^{3} / \mathrm{s}$ at USGS streamgage 12113000 . Turbidity during the study period ranged from 1.3 to $260 \mathrm{FNU}$.

The 35 discrete samples of SSC and SSC FINES were collected over a representative range of river conditions, with discharge ranging from 83.9 to $7,650 \mathrm{ft}^{3} / \mathrm{s}$ (fig. 9) and turbidity ranging from 2.8 to $220 \mathrm{FNU}$ (fig. 10). SSC concentrations ranged from 6 to $555 \mathrm{mg} / \mathrm{L}$, with a median SSC of $31 \mathrm{mg} / \mathrm{L}$ (table 2). The SSCFInES concentrations ranged from 5 to $383 \mathrm{mg} / \mathrm{L}$ (56 to 95 percent of SSC, respectively), with a median SSCFINES of $25.9 \mathrm{mg} / \mathrm{L}$ (table 2). 


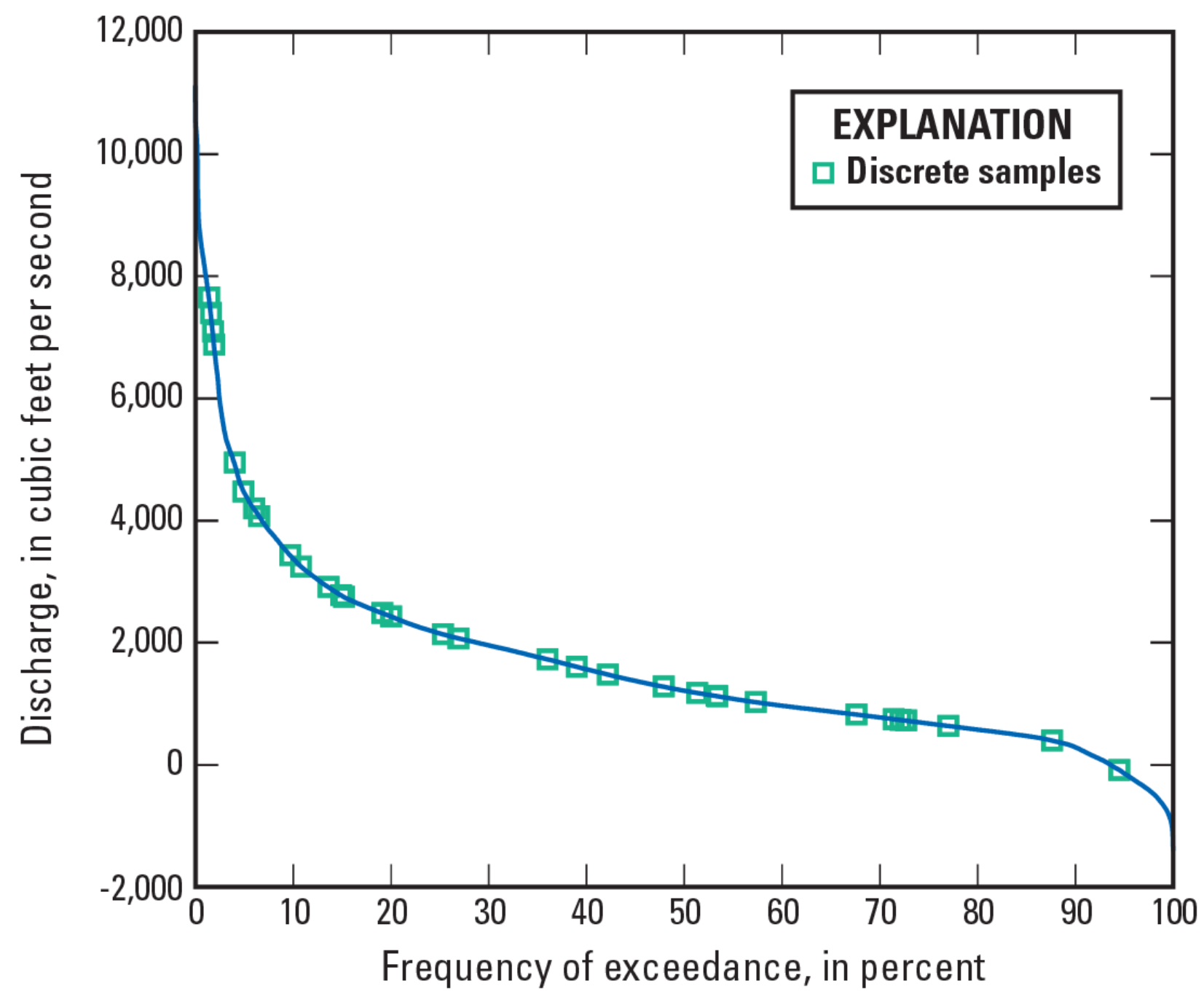

Figure 9. Discharge duration curve, U.S. Geological Survey streamgage 12113390 (Duwamish River at Golf Course at Tukwila, WA), November 2013-January 2017. 


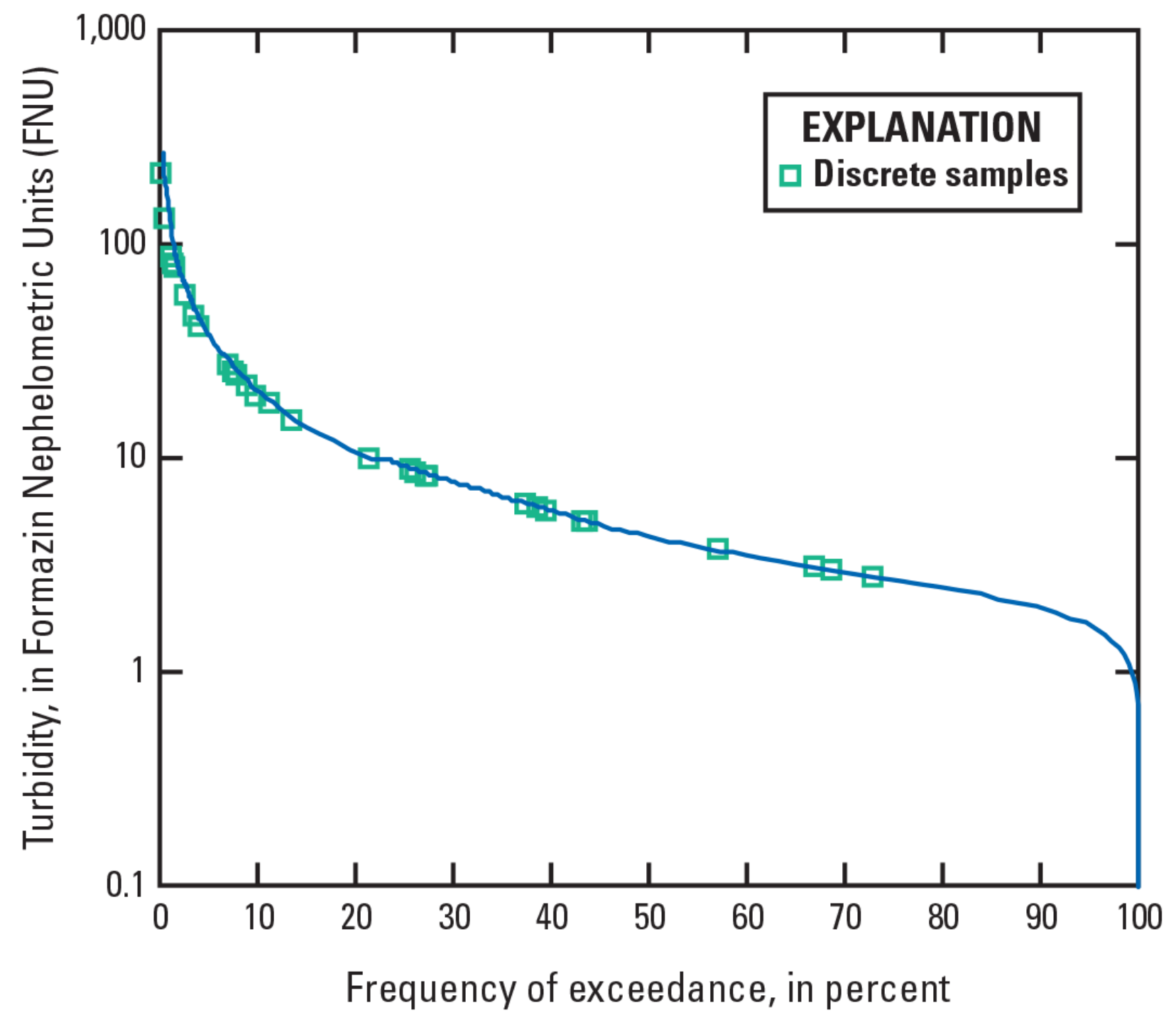

Figure 10. Turbidity duration curve, U.S. Geological Survey streamgage 12113390 (Duwamish River at Golf Course at Tukwila, WA), November 2013-January 2017. 
Table 2. Suspended-sediment concentration, suspended-sediment concentration of fines, turbidity, and discharge samples collected at U.S. Geological Survey streamgage 12113390 (Duwamish River at Golf Course at Tukwila, WA).

[SSC: Suspended-sediment concentration. SSC FiNES: Suspended-sediment concentration of particles less than 0.0625 millimeter in diameter. Turbidity: Approved median 15-minute DTS-12 value for associated SSC sample duration, $\mathrm{R}$ - SonTek ${ }^{\circledR}$ YSI 6920-V2-2 versus DTS-12 linear regression derived value. Discharge: Approved median 15-minute value for associated SSC sample duration; ${ }_{\mathrm{D}}$, discrete discharge measurement taken for associated SSC sample.

Abbreviations: mg/L, milligram per liter; FNU, Formazin Nephelometric Unit; $\mathrm{ft}^{3} / \mathrm{s}$, cubic foot per second]

\begin{tabular}{|c|c|c|c|c|}
\hline & $\begin{array}{l}\text { SSC } \\
\text { (mg/L) }\end{array}$ & $\begin{array}{c}\mathrm{SSC}_{\text {FINES }} \\
(\mathrm{mg} / \mathrm{L})\end{array}$ & $\begin{array}{l}\text { Turbidity } \\
\text { (FNU) }\end{array}$ & $\begin{array}{c}\text { Discharge } \\
\left(\mathrm{ft}^{3} / \mathrm{s}\right)\end{array}$ \\
\hline $02 / 07 / 2013$ & 12 & 7.32 & $8.4_{R}$ & $2,430_{D}$ \\
\hline $03 / 13 / 2013$ & 7 & 5.6 & $5.7_{\mathrm{R}}$ & $1,480_{D}$ \\
\hline $04 / 05 / 2013$ & 17 & 10.37 & $8.3 \mathrm{R}$ & $2,490 D$ \\
\hline $04 / 08 / 2013$ & 81 & 35.64 & $27.5_{R}$ & $4,950_{D}$ \\
\hline $05 / 13 / 2013$ & 31 & 18.91 & $\mathrm{~N} / \mathrm{A}$ & $2,750_{D}$ \\
\hline $06 / 19 / 2013$ & 6 & 5.04 & N/A & $727 D$ \\
\hline $11 / 21 / 2013$ & 71 & 56.8 & 22 & N/A \\
\hline $12 / 02 / 2013$ & 169 & 118.3 & 58 & 4074 \\
\hline $01 / 11 / 2014$ & 56 & 48.16 & 25 & 3434 \\
\hline $02 / 14 / 2014$ & 76 & 62.32 & 26 & 2,910 \\
\hline $02 / 18 / 2014$ & 145 & 81.2 & 47 & 4,198 \\
\hline $03 / 06 / 2014$ & 327 & 222.36 & 81 & 7,400 \\
\hline $04 / 17 / 2014$ & 15 & $\mathrm{~N} / \mathrm{A}$ & 6.1 & 1,730 \\
\hline $06 / 11 / 2014$ & 9 & 7.56 & 2.8 & 828 \\
\hline $07 / 23 / 2014$ & 45 & 42.75 & 15 & 738 \\
\hline $09 / 24 / 2014$ & 31 & 23.56 & $\mathrm{~N} / \mathrm{A}$ & 640 \\
\hline $10 / 08 / 2014$ & 9 & 7.47 & $5.9_{R}$ & 753 \\
\hline $10 / 22 / 2014$ & 19 & 15.2 & $8.9_{\mathrm{R}}$ & 1,126 \\
\hline $10 / 23 / 2014$ & 56 & 45.36 & $18.4_{R}$ & 1,607 \\
\hline $11 / 20 / 2014$ & 9 & 8.28 & $\mathrm{~N} / \mathrm{A}$ & 1,182 \\
\hline $11 / 25 / 2014$ & 41 & 28.29 & $19.8_{R}$ & 3,247 \\
\hline $11 / 26 / 2014$ & 410 & 274.7 & $135 \mathrm{R}$ & $7,100 \mathrm{D}$ \\
\hline $12 / 22 / 2014$ & 222 & 175.38 & 78.5 & 4,478 \\
\hline $01 / 06 / 2015$ & 555 & 382.95 & 220 & 7,653 \\
\hline $01 / 08 / 2015$ & 267 & 192.24 & 88 & 6,884 \\
\hline $02 / 05 / 2015$ & 35 & 32.9 & 10 & 2,073 \\
\hline $02 / 26 / 2015$ & 6 & 4.8 & 3 & 1,282 \\
\hline $08 / 30 / 2016$ & 7 & 5.88 & 3.7 & 400 \\
\hline $09 / 27 / 2016$ & 9 & 7.74 & 3.1 & 83.9 \\
\hline $10 / 07 / 2016$ & 7 & 4.69 & 5 & 1,030 \\
\hline $12 / 20 / 2016$ & 11 & 10.23 & 8.7 & 2,140 \\
\hline $01 / 11 / 2017$ & 8 & 7.28 & 5.1 & 1,130 \\
\hline $01 / 18 / 2017$ & 58 & 55.1 & 42 & 2,780 \\
\hline
\end{tabular}




\section{Regression Results}

Four regression models were used to compute 15-minute SSC and $\mathrm{SSC}_{\text {FINES. The following }}$ describes each regression model in more detail.

\section{Suspended-Sediment Concentration-Turbidity Regression}

A log-transformed least-squares regression model for the relation between discrete samples of SSC and concurrently measured turbidity was selected based on analysis of diagnostic statistics and model residuals consistent with Rasmussen and others (2009). Both the SSC-turbidity model and the $\log (\mathrm{SSC})-\log$ (turbidity) model had high $\mathrm{R}^{2}$ values $(>0.9)$ and low standard errors. However, the variance of the residuals for the untransformed regression indicated a heteroscedastic pattern in which the variability of the residuals increased as estimated SSC values increased. The variance of the residuals for the $\log _{10}$-transformed regression indicated a homoscedastic pattern and a more normal distribution. This resulted in a higher probability plot correlation coefficient ( 0.991 versus 0.858$)$ indicative of a correlation that meets the assumptions of a statistically valid regression model. The regression between $\log _{10} \mathrm{SSC}$ and $\log _{10}$ turbidity was selected and had an $\mathrm{R}^{2}$ of 0.952 (fig. $11 A$; table 1).

\section{Suspended-Sediment Concentration Fines (Particles Less Than 0.0625 Millimeter in Diameter)-Turbidity Regression}

Similar to the SSC-turbidity regression, both the untransformed and the $\log _{10}$ transformed regressions performed well for $\mathrm{SSC}_{\mathrm{FINES}}$ and turbidity, but the $\log _{10}$ transformed regression was selected based on the more normal distribution of the variance of the residuals, as indicated by a higher probability plot correlation coefficient (0.992 vs. 0.932$)$. The regression between $\log _{10} \mathrm{SSC}_{\mathrm{FINES}}$ and $\log _{10}$ turbidity had an $\mathrm{R}^{2}$ of 0.936 (fig. $11 B$; table 1 ).

\section{Suspended-Sediment Concentration-Discharge Regression}

The regression between $\log _{10} \mathrm{SSC}$ and $\log _{10}$ discharge was selected based on the more normal distribution of the variance of the residuals, as indicated by a higher probability plot correlation coefficient (0.984 versus 0.966$)$. The $\mathrm{R}^{2}$ for this model was 0.584 (fig. $11 C$; table 1 ).

\section{Suspended-Sediment Concentration (Particles Less Than 0.0625 Millimeter in Diameter)-Discharge Regression}

Similar to the SSC-discharge regression, the regression between $\log _{10} \mathrm{SSC}_{\mathrm{FINES}}$ and $\log _{10}$ discharge was selected based on the more normal distribution of the variance of the residuals, as indicated by a higher probability plot correlation coefficient $(0.988$ versus 0.965$)$. The $\log _{10}$ transformed regression was selected and had an $\mathrm{R}^{2}$ of 0.539 (fig. $11 D$; table 1).

At very low discharge in both downstream and upstream (-) directions, between 218 and -218 $\mathrm{ft}^{3} / \mathrm{s}$, the regression models computed SSC values that were less than the corresponding SSC $\mathrm{FINES}$ values, which does not make physical sense. This is a limitation of using discharge as the surrogate to compute suspended-sediment concentrations. However, the impact to the overall load estimates was very minimal. For the entire period of record, the amount of SSLFines load that was more than the paired SSL total load was $0.022-0.042$ tons in the downstream direction and 0.02 ton in the upstream direction - which is insignificant considering the total load for the study period (371,000 tons). The upper and lower 90 percent confidence bounds (U90, L90) for the regression models further show the advantage of using turbidity, rather than discharge, to compute SSC (fig. 11). 

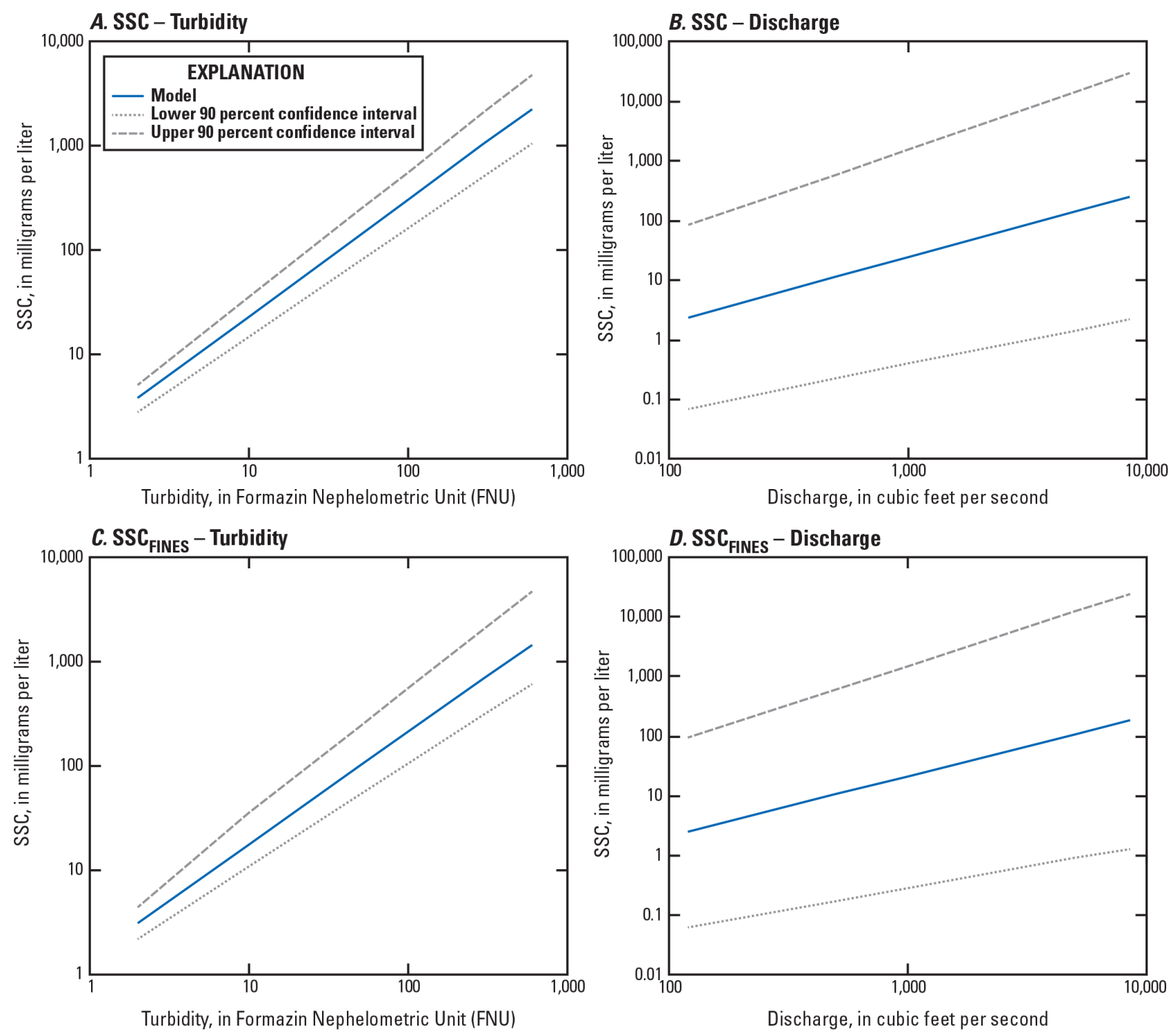

Figure 11. Suspended-sediment concentration (SSC) regression model plots with associated upper and lower 90 percent confidence bounds. (A) log10 SSC versus log10 Turbidity; (B) log10 SSC versus log10 Discharge; (C) $\log 10$ SSC fines versus log10 Turbidity; (D) log10 SSC fines versus log10 Discharge. SSCFINES, suspendedsediment concentration of particles less than 0.0625 millimeter in diameter. 


\section{Time-Series Suspended-Sediment Concentration and Load Calculations}

When turbidity data were available (93.5 percent of time), an otherwise continuous 15-minute record of SSC from November 2013 through January 2017 was determined from the $\log _{10}$ SSC- $\log _{10}$ turbidity regression and corrected for bias resulting from the log transformation (Helsel and Hirsch, 2002; Rasmussen, 2009). During periods when turbidity data were missing (December 4, 2013; September 28-December 5, 2014; September 22-24, 2015; April 16-17, 2016; July 24-25, 2016; and September 15-19, 2016), the $\log _{10} \mathrm{SSC}-\log _{10} \mathrm{Q}$ regression was applied and similarly corrected for transformation bias.

The resulting SSC time-series is in Senter and others (2018). During the 1,160-day study period, the calculated 15-minute SSC ranged from a minimum of less than $1 \mathrm{mg} / \mathrm{L}$ to a maximum of $872 \mathrm{mg} / \mathrm{L}$, with a median of $9.5 \mathrm{mg} / \mathrm{L}$. The SSC values were converted to 15 -minute suspendedsediment loads (SSL) by multiplying SSC and discharge for each 15-minute time step. The total SSL during the 1,160-day study period was 371,000 tons (336,000 metric tons), resulting in an average of 319 tons/d (289 metric tons/d) and 117,000 tons/yr (106,000 metric tons/yr).

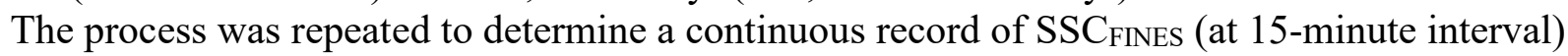
for the same period of record. The resulting $\mathrm{SSC}_{\mathrm{FINES}}$ time-series is reported in Senter and others (2018). During the 1,160-day study period, the calculated $\mathrm{SSC}_{\mathrm{FINES}}$ ranged from a minimum of less than $1 \mathrm{mg} / \mathrm{L}$ to a maximum of $600 \mathrm{mg} / \mathrm{L}$, with a median of $7.7 \mathrm{mg} / \mathrm{L}$. The $\mathrm{SSC}_{\text {FINES values were }}$ converted to 15-minute fine suspended-sediment loads (SSLFINES). The total SSLFINES during the 1,160-day study period was 273,000 tons (247,000 metric tons), resulting in an average of 235 tons/d (213 metric tons/d) and 85,800 tons/yr (77,800 metric tons/yr). On average, approximately 74 percent of the total suspended-sediment load was comprised of fine particles less than $0.0625 \mathrm{~mm}$ in diameter.

The majority of the average annual SSL ( 97 percent) occurred during the wet season of the year, from October 16 to April 15. During the 1,160-day study period, there were 455 days when, at some time during the day, there was negative load (suspended-sediment load moving in the upstream direction). The majority of the days in which upstream load was present occurred during the dry season, when there are significantly lower SSCs. Therefore, the total calculated SSL in the upstream direction was only 415 tons (376 metric tons), resulting in an average of 131 tons/yr (119 metric tons/yr), or 0.001 percent of the total suspended-sediment load.

\section{Comparison to Previous Sediment Load Estimates}

The 3-year average annual sediment load estimate $(117,000$ tons/yr) is within the range of previously-reported estimates of sediment load, which have ranged from approximately 50,000 to 500,000 tons/yr, because of large inter-annual variability in discharge and suspended-sediment concentration (Embrey and Frans, 2003; Lower Duwamish Waterway Group, 2008; Gries and Sloan, 2009). The new estimate may better represent current river conditions because: 
Discrete and time-series data were collected in 2013-17, whereas previous estimates were based on data collected in the 1960s and 1990s. Particularly, discrete water samples for SSC were collected using isokinetic depth- and flow-integrated techniques, including large-volume (5-15 L) replicate ("A" and "B" set) samples for an averaged result. Samples from the 1960 s were daily singlevertical samples. Samples from the 1990s were a single 1-L sample split from an isokinetic depth- and width-integrated composite.

- Previous estimates were based on regressions with discharge from the streamgage at RKM 48, USGS streamgage 12113000. For example, the discharge parameter used in the Embrey and Frans (2003) regression for estimating SSL was based on a relation between discrete measurements of discharge at USGS streamgage 12113390 in Tukwila and continuous discharge at USGS streamgage 12113000 in Auburn. The current estimate is based on regressions with turbidity (unless it was unavailable), which is a better surrogate for SSC than discharge (as indicated by improved model performance, see Senter and others, 2018). Loads also were calculated with discharge in Tukwila (RKM 16.7), which is closer to the LDW and has discharge values approximately 15 percent higher than at the Auburn streamgage.

- The sediment load accounts for upstream loading in the tidally influenced portion of the river (total $=$ downstream - upstream). Although the upstream load is negligible $(<0.01$ years $)$ at the sampling station (RKM 16.7), the results highlight the frequency and extent of tidal influence in the river (backwater conditions on approximately 41 percent of days each year). A remaining data gap is the contribution of the upstream load to the total sediment load at the LDW boundary (RKM 8).

This report captures 3 complete calendar years (2014-16) of sediment load estimates. The years within the study period appear to be a good representation of historic conditions (fig. 12). However, the combination of drought conditions from March to November 2015 and the magnitude and frequency of high-flow events that occurred from November through December 2015 could explain the significantly higher SSL computed for 2015. Because of the significant difference in computed loads based on seasonality, annual load estimates should be calculated by averaging the estimates of each individual year, rather than extrapolating daily averages from the entire study period. Calculating each of the complete calendar years (2014-16) gives a total SSL of 97,200 tons (2014), 190,000 tons (2015), and 65,000 tons (2016). The average annual load of the 3 years gives a total SSL of 117,000 tons. This study does not capture long-term decadal weather patterns that influence the Pacific Northwest (for example, El Nino/La Nina). This also is an estimate of suspended-sediment load, and does not include a separate estimate of bedload transport, which is highly variable and may contribute a large additional sediment load under high-flow conditions. 
USGS 12113000 Green River near Auburn, WA
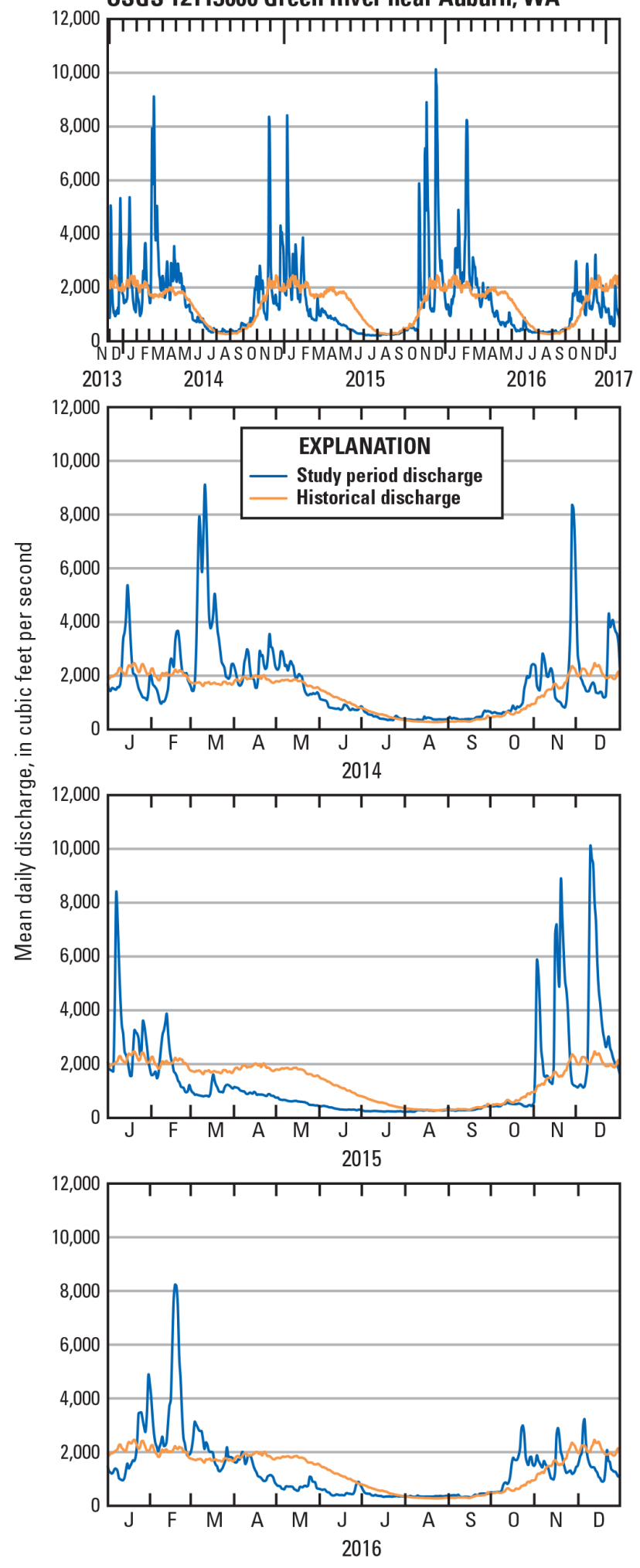

Figure 12. Daily mean discharge for study period with overlapping historical mean daily discharge, U.S. Geological Survey streamgage 12113000 (Green River near Auburn, WA), Washington. 


\section{Summary}

Between February 2013 and January 2017, the U.S. Geological Survey, in cooperation with the Washington State Department of Ecology, collected discrete and time-series data to estimate continuous SSC and SSL to the LDW from upstream sources transported by the Green River, Washington. The estimate for the 3-year average annual SSL for this study is 117,000 tons $(106,000$ metric tons) and 86,200 tons (78,200 metric tons) for average annual SSLFINES. Targeted sampling periods for suspended-sediment sampling were during heavy rainfall events, large dam releases, as well as typical conditions, when there were neither heavy rainfall events nor large dam releases. Streamflow and suspended-sediment concentrations were highest from October 16 to April 15 of each year.

\section{Acknowledgments}

This work was completed under USGS-Ecology Interagency Agreements 13WNWA30005, 14WNWA30005, and 16WNWA30005. We are grateful to Curt Chandler and staff at the Foster Golf Course in Tukwila, Washington, for access and use of the bridge and facilities throughout the project. The following USGS employees and volunteers provided invaluable field and laboratory help: Andrew Gendaszek, Raegan Huffman, Greg Justin, Cameron Marshall, Chad Opatz, Karen Payne, Amber Powell, Stephen Sissel, Rich Sheibley, Andrew Spanjer, David Steele, and Alison Tecca. We are indebted to the USGS peer-reviewers for their insightful comments, which greatly improved the quality of the report.

\section{References Cited}

Conn, K.E., and Black, R.W., 2014, Data compilation for assessing sediment and toxic chemical loads from the Green River to the lower Duwamish Waterway, Washington: U.S. Geological Survey Data Series 880, 46 p., accessed March 1, 2016, at https://dx.doi.org/10.3133/ds880.

Conn, K.E., Black, R.W., Vanderpool-Kimura, A.M., Foreman, J.R., Peterson, N.T., Senter, C.A., and Sissel, S.K., 2015, Chemical concentrations and instantaneous loads, Green River to the Lower Duwamish Waterway near Seattle, Washington, 2013-15: U.S. Geological Survey Data Series 973, 46 p., accessed March 1, 2016, at https://dx.doi.org/10.3133/ds973.

Davis, B.E., 2001, The US D-96-An isokinetic suspended-sediment/water-quality collapsible-bag sampler: Federal Interagency Sedimentation Project Report PP, 41 p., accessed February 18, 2016, at https://water.usgs.gov/fisp/docs/Report_PP,_US_D-96_011114.pdf.

Domanski, M.M., Straub, T.D., and Landers, M.N., 2015, Surrogate analysis and index developer (SAID) tool (version 1.0, September 2015): U.S. Geological Survey Open-File Report 2015-1177, 38 p., https://dx.doi.org/10.3133/20151177.

Edwards, T.K., and Glysson, G.D., 1999, Field methods for measurement of fluvial sediment:

Techniques of Water-Resources Investigations of the U.S. Geological Survey, book 3, chap. C2, accessed December 4, 2012, at https://pubs.usgs.gov/twri/twri3-c2/html/pdf.html.

Embrey, S.S., and Frans, L.M., 2003, Surface-water quality of the Skokomish, Nooksack, and GreenDuwamish Rivers and Thornton Creek, Puget Sound Basin, Washington, 1995-98: U.S. Geological Survey Water-Resources Investigations Report 2002-4190, accessed March 8, 2013, at https://pubs.er.usgs.gov/publication/wri024190.

Gries, T., and Sloan, J., 2009, Contaminant loading to the Lower Duwamish Waterway from suspended sediment in the Green River, Washington: Washington State Department of Ecology Publication No. 09-03-028, 118 p. 
Guy, H.P., 1969, Laboratory theory and methods for sediment analysis: Techniques of WaterResources Investigations, book 5, chap. C1, accessed September 10, 2013, at https://pubs.usgs.gov/twri/twri5c1/html/pdf.html.

Helsel, D.R., and Hirsch, R.M., 2002, Statistical methods in water resources: U.S. Geological Survey Techniques of Water Resources Investigations, book 4, chap. A3, 522 p.

Levesque, V.A., and Oberg, K.A., 2012, Computing discharge using the index velocity method: U.S. Geological Survey Techniques and Methods, book 3, chap. A23, 148 p., https://pubs.usgs.gov/tm/3a23/.

Lower Duwamish Waterway Group, 2008, Lower Duwamish Waterway sediment transport modeling report final: Montvale, New Jersey, Quantitative Environmental Analysis, LLC, prepared for U.S. Environmental Protection Agency and Washington State Department of Ecology (Northwest Regional Office, Bellevue, WA), accessed December 4, 2012, at www.ldwg.org/rifs_docs4.htm\#stm. Rasmussen, P.P., Gray, J.R., Glysson, G.D., and Ziegler, A.C., 2009, Guidelines and procedures for computing time-series suspended-sediment concentrations and loads from in-stream turbidity-sensor and streamflow data: U.S. Geological Survey Techniques and Methods, book 3, chap. C4, 53 p., accessed March 1, 2016, at https://pubs.usgs.gov/tm/tm3c4/.

Santos, J.F., and Stoner, J.D., 1972, Physical, chemical, and biological aspects of the Duwamish River Estuary, King County, Washington, 1963-67: U.S. Geological Survey Water-Supply Paper 1873-C, $74 \mathrm{p}$.

Senter, C.A., Conn, K.E., Black, R.W., Peterson, N., Vanderpool-Kimura, A., and Foreman, J.R., 2018, Data for turbidity, discharge, and suspended-sediment concentrations and loads, Duwamish River, Tukwila, Washington: U.S. Geological Survey data release, https://doi.org/10.5066/F71835Q9.

Turnipseed, D.P., and Sauer, V.B., 2010, Discharge measurements at gaging stations: U.S. Geological Survey Techniques and Methods, book 3, chap. A8, 87 p., https://pubs.usgs.gov/tm/tm3-a8/.

U.S. Environmental Protection Agency, 2018, Superfund-CERCLA overview: U.S. Environmental Protection Agency, accessed January 1, 2018, at https:/www.epa.gov/superfund/superfund-cerclaoverview.

U.S. Geological Survey, 2017, National Water Information System: U.S. Geological Survey web interface, accessed September 26, 2017, at https://doi.org/10.5066/F7P55KJN.

Wagner, R.J., Boulger, R.W., Oblinger, C.J., and Smith, B.J., 2006, Guidelines and standard procedures for continuous water-quality monitors - Station operation, record computation, and data reporting: U.S. Geological Survey Techniques and Methods 1-D3, 51 p., accessed November 1, 2013, at https://pubs.er.usgs.gov/publication/tm1D3.

Washington State Department of Ecology, 2013 (rev.), Model Toxics Control Act Regulation and Statute: Washington State Department of Ecology, 324 p. 

Publishing support provided by the U.S. Geological Survey

Science Publishing Network, Tacoma Publishing Service Center

For more information concerning the research in this report, contact the Director, Washington Water Science Center

U.S. Geological Survey

934 Broadway, Suite 300

Tacoma, Washington 98402

https://wa.water.usgs.gov 
를

웋 